\title{
Fine-Needle Aspiration Cytology in the Diagnosis of Lymph Nodes: Correlation with Histopathological Diagnosis
}

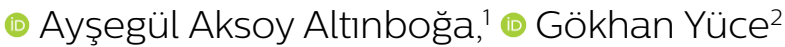

\author{
'Department of Pathology, Ankara \\ Yıldırım Beyazıt University Faculty \\ of Medicine, Ankara, Turkey \\ 2Department of Radyology, Ankara \\ Atatürk Training and Research \\ Hospital, Ankara, Turkey \\ Submitted: 06.11.2018 \\ Accepted: 04.02.2019 \\ Correspondence: \\ Ayşegül Aksoy Altınboğa, \\ Ankara Atatürk Eğitim ve Araştırma \\ Hastanesi, Patoloji Kliniği, Bilkent, \\ 06800 Ankara, Turkey \\ E-mail: aysegulaksoy@hotmail.com

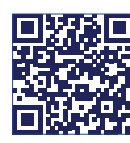 \\ Keywords: Accuracy; fine- \\ needle aspiration cytology; \\ histopathology; lymph nodes.
}

\begin{abstract}
Objective: Lymph node fine-needle aspiration cytology (FNAC) is usually the first step in the evaluation of an enlarged lymph node. It is a rapid, minimally invasive, and less expensive procedure than histopathological examination. The aim of this study was to analyze the diagnostic adequacy of lymph node FNAC compared with histopathological diagnosis.
\end{abstract}

Methods: A total of 171 lymph node FNAC results performed between 2016 and 2017 were reviewed for inclusion in this study. In all, the FNAC results of $4 \mathrm{I}$ cases sampled with Tru-Cut (Merit Medical Systems, Inc., South Jordan, UT, USA) and/or excisional biopsy were compared with the histopathological findings.

Results: The FNAC diagnosis of 13 benign cases (13/I3), 3 reported as atypia of undetermined significance (3/4), 8 that were suspected malignancy (8/9), and 13 malignant cases (13/13) were well correlated with the final histopathological diagnoses. The overall diagnostic sensitivity, specificity, positive predictive value, negative predictive value, and accuracy were found to be $95.4 \%, 94.1 \%, 95.4 \%, 94.1 \%$, and $94.9 \%$ respectively. The false negative rate was $2.4 \%$ and the false positive rate was $2.4 \%$.

Conclusion: FNAC of lymph nodes is a highly sensitive and specific method to diagnose lymph node pathologies. It is a reliable diagnostic tool in the evaluation of an enlarged lymph node.

\section{INTRODUCTION}

The lymph node is an important part of the body's defense system. It may become enlarged due to stimulation by infectious agents or the involvement of metastasis or malignant diseases, such as lymphoma, and may lead to a patient consultation with a doctor due to a growing mass. ${ }^{[1]}$ The patient's age, whether the affected lymph node is painful or not, and the growth rate, as well as its ultrasonographic dimensions, shape, internal structure as visualized on grayscale ultrasound, and the vascular pattern observed in Doppler mode, provide preliminary information whether or not an affected lymph node may be benign or malignant. ${ }^{[2]}$ A tissue biopsy is accepted as the gold standard method for the diagnosis of lymph node pathologies, as in other head and neck masses. ${ }^{[3]}$ However, when an excisional biopsy is performed, complications such as scar tissue formation, bleeding, neurovascular injury, and a long healing process have been observed in the excised area. ${ }^{[3,4]}$

Currently, fine-needle aspiration cytology (FNAC), which has the advantages of minimal trauma and rapid diagnosis, is widely used as the first tool of diagnosis and management for patients who present with lymphadenopathy. ${ }^{[5]}$
There are studies in the literature reporting that FNAC is reliable in the diagnosis of lymphadenopathies; ${ }^{[6,7]}$ however, there are also studies reporting opposing views. ${ }^{[8,9]}$ The aim of this study was to investigate the diagnostic effectiveness of lymph node FNAC findings compared with histopathological results.

\section{MATERIAL AND METHODS}

The records of patients who underwent FNAC with the indication of lymphadenopathy at this institution between 2016 and 2017 were retrieved from a scan of archive materials. All of the lymph nodes were sampled by a radiologist with the aid of ultrasonography. Each lesion was aspirated between I and 3 times using a 2I-G needle. Samples of the aspiration material were spread directly on slides, air-dried, and stained with May-Grünwald-Giemsa stain.

The cytology samples were reported as nondiagnostic, benign, atypia of undetermined significance, suspected malignancy, or malignant. Patients without a corresponding histopathological result were excluded from the study. The results of patients who underwent Tru-Cut (Merit Medical 
Table I. Distribution of cyto-histopathological diagnoses of cases with tissue correlation

\begin{tabular}{lcccccc}
\hline Histopathological diagnosis & \multicolumn{3}{c}{ Cytological diagnosis } & Total \\
\cline { 2 - 6 } & Non-diagnostic & Benign & $\begin{array}{c}\text { Atypia of undetermined } \\
\text { significance }\end{array}$ & $\begin{array}{c}\text { Suspected } \\
\text { malignancy }\end{array}$ & Malignancy \\
\hline Benign & 0 & 13 & 3 & 1 & 0 & 17 \\
Suspected malignancy & 0 & 0 & 0 & 3 & 0 & 3 \\
Malignant & 2 & 0 & 1 & 5 & 13 & 21 \\
Total & 2 & 13 & 4 & 9 & 13 & 41 \\
\hline
\end{tabular}

Systems, Inc., South Jordan, UT, USA) or excisional biopsy and the cytopathological results were compared with the histopathological diagnoses.

The cytopathological diagnoses were divided into categories of benign (known benign groups and groups of atypia of undetermined significance) and malignant (malignant and suspected malignancy) and compared with the histopathological diagnoses.

Classifications of true negative (TN; histopathologically confirmed benign cytopathological diagnosis), true positive
(TP; histopathologically confirmed malignant cytological diagnosis), false negative (FN: Histopathologic diagnosis: maligant and cytopathologc diagnosis benign), false positive (FP; histopathologic diagnosis: benign and cytopathologic diagnosis: malignant) were determined.

The sensitivity (sensitivity: TP/TP+FNXI00), specificity (spesificity: TN/TN+FPXI00), accuracy (accuracy: TP+TN/ $\mathrm{TP}+\mathrm{TN}+\mathrm{FP}+\mathrm{FN})$, positive predictive value $(\mathrm{PPV}=\mathrm{TP} /$ $\mathrm{TP}+\mathrm{FP} \times 100)$ and the negative predictive value (NPV=TN/ $\mathrm{TN}+\mathrm{FN} \times 100)$ was calculated.
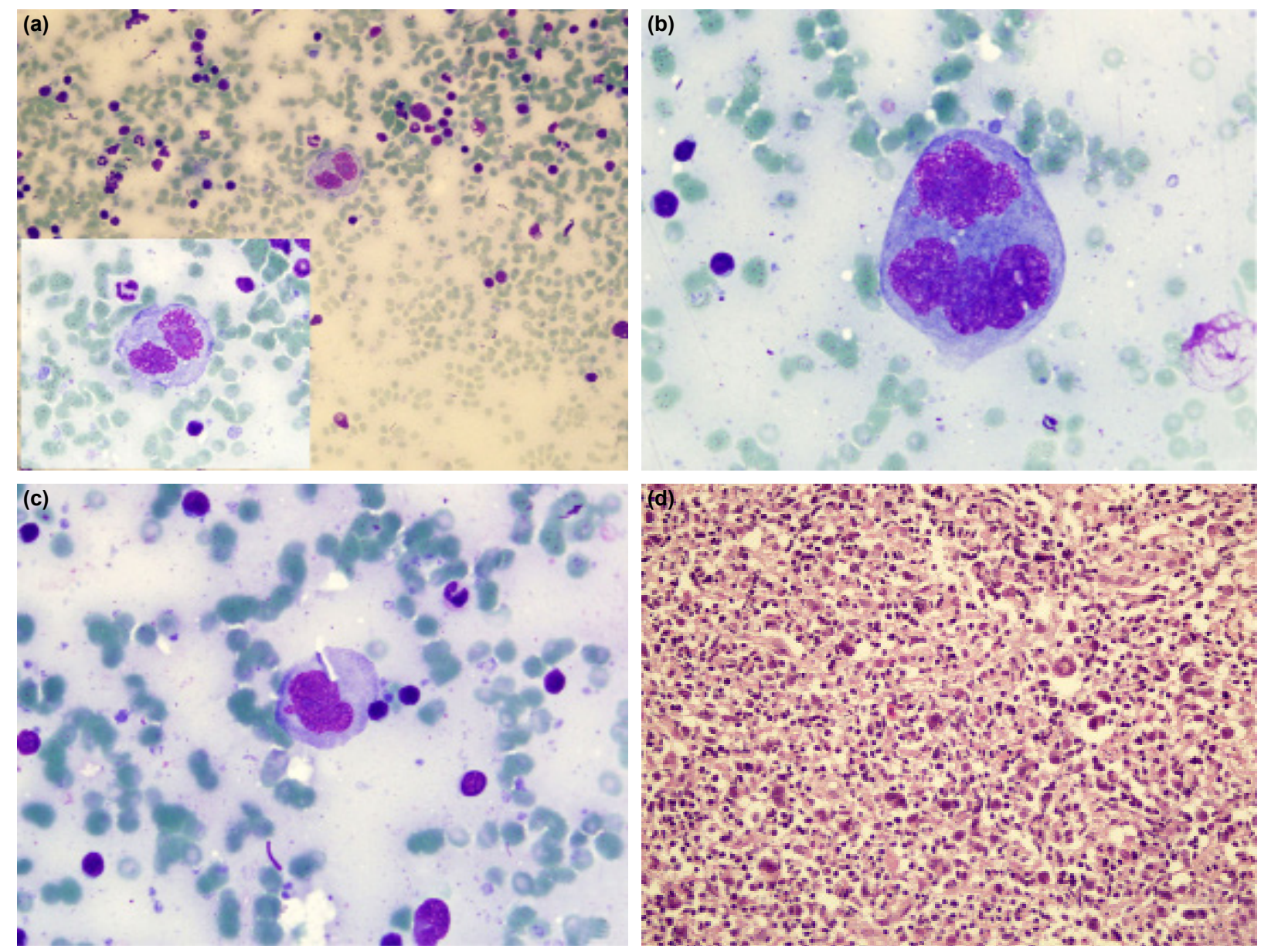

Figure 1. (a) Binuclear Reed-Sternberg cells seen in the background with lymphocytes and eosinophil leukocytes (May-GrünwaldGiemsa [MGG] x 400, internal image; MGG x1000), (b) Multinuclear Hodgkin's cell with clustered chromatin and hyperchromatic nucleus (MGG x1000), (c) Hodgkin's cell (MGG x1000), (d) Reed-Sternberg cells with mononuclear and multinuclear Hodgkin's cells on mixed cellular background from a Tru-Cut biopsy section (Hematoxylin and eosin x200). 


\section{RESULTS}

In all, I7I patients underwent FNAC for lymphadenopathy between 2016 and 2017 at this hospital. Of the total, 104 (61\%) patients were female and 67 (39\%) of them were male. The mean age of the patients was 44.5 years (minmax: 8-85 years). The specimens were obtained from the axillary $(n=18)$, lower jugular $(n=5)$, inguinal $(n=2)$, midjugular $(n=5)$, paratracheal $(n=3)$, cervical $(n=13)$, sub- mandibular $(n=76)$, submental $(n=6)$, supraclavicular $(n=9)$, and upper jugular lymph nodes $(n=34)$.

The FNAC results of the specimens were reported as nondiagnostic $(n=24,14 \%)$, benign $(n=I I I, 65 \%)$, atypia of undetermined significance $(4,2.3 \%)$, suspected malignancy $(n=10,5.8 \%)$, and malignant $(n=22,12.9 \%)$. Histopathological correlations were detected in patients who underwent Tru-Cut biopsy $(n=28)$, excisional biopsy $(n=10)$, and TruCut followed by excisional biopsy $(n=3)$ (Table I).
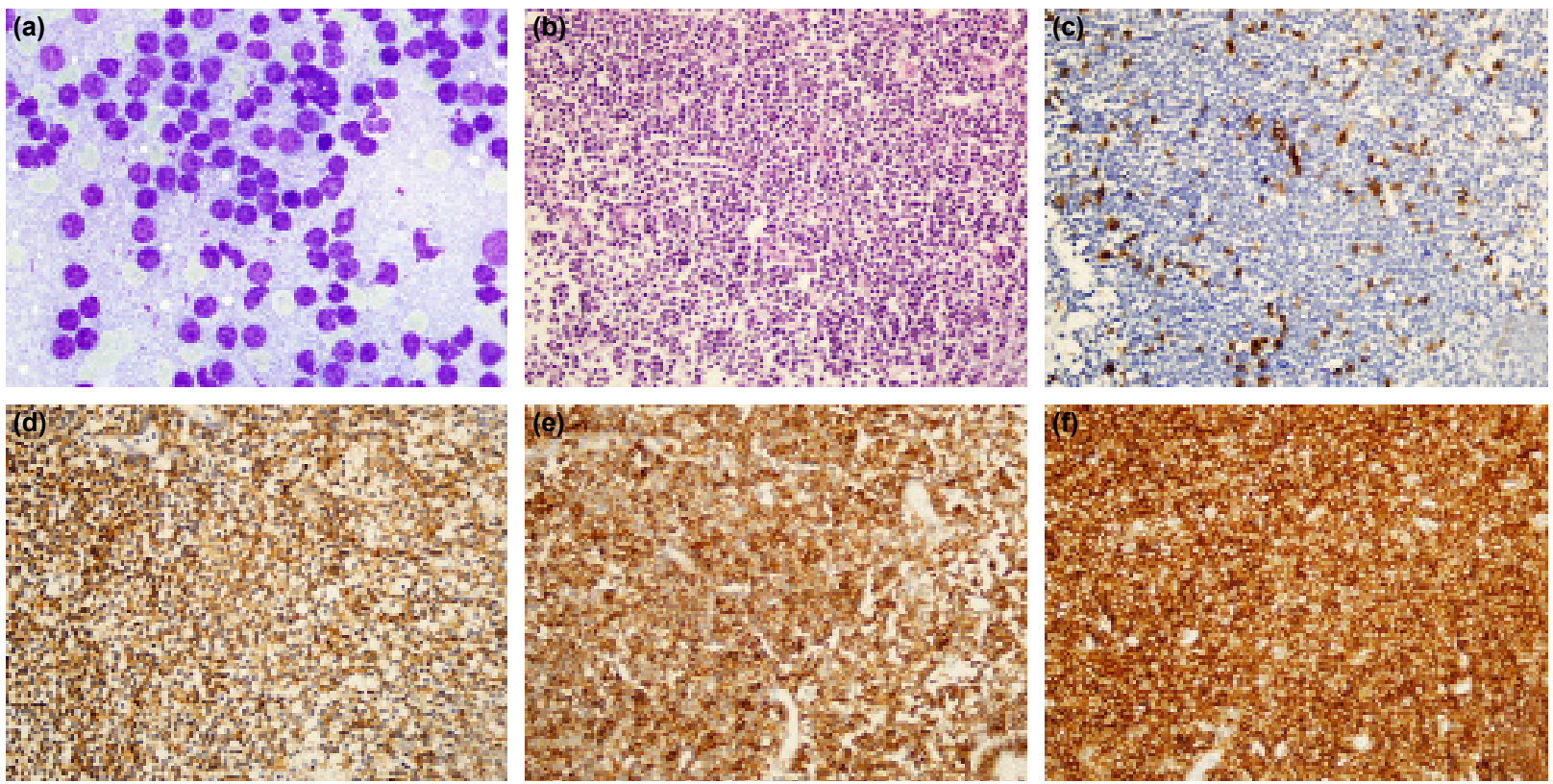

Figure 2. (a) Diffuse infiltration of small lymphoid cells with clustered chromatin seen in some small micronuclear cells (May-GrünwaldGiemsa x1000), (b) Small lymphocytes demonstrating diffuse infiltration (Hematoxylin and eosin x200) in a Tru-Cut biopsy section, (c) CD3 demonstrate reactive T lymphocytes, (d, e) small lymphocytes exibit diffuse immune expression with CD20 (d) and CD23 (f).
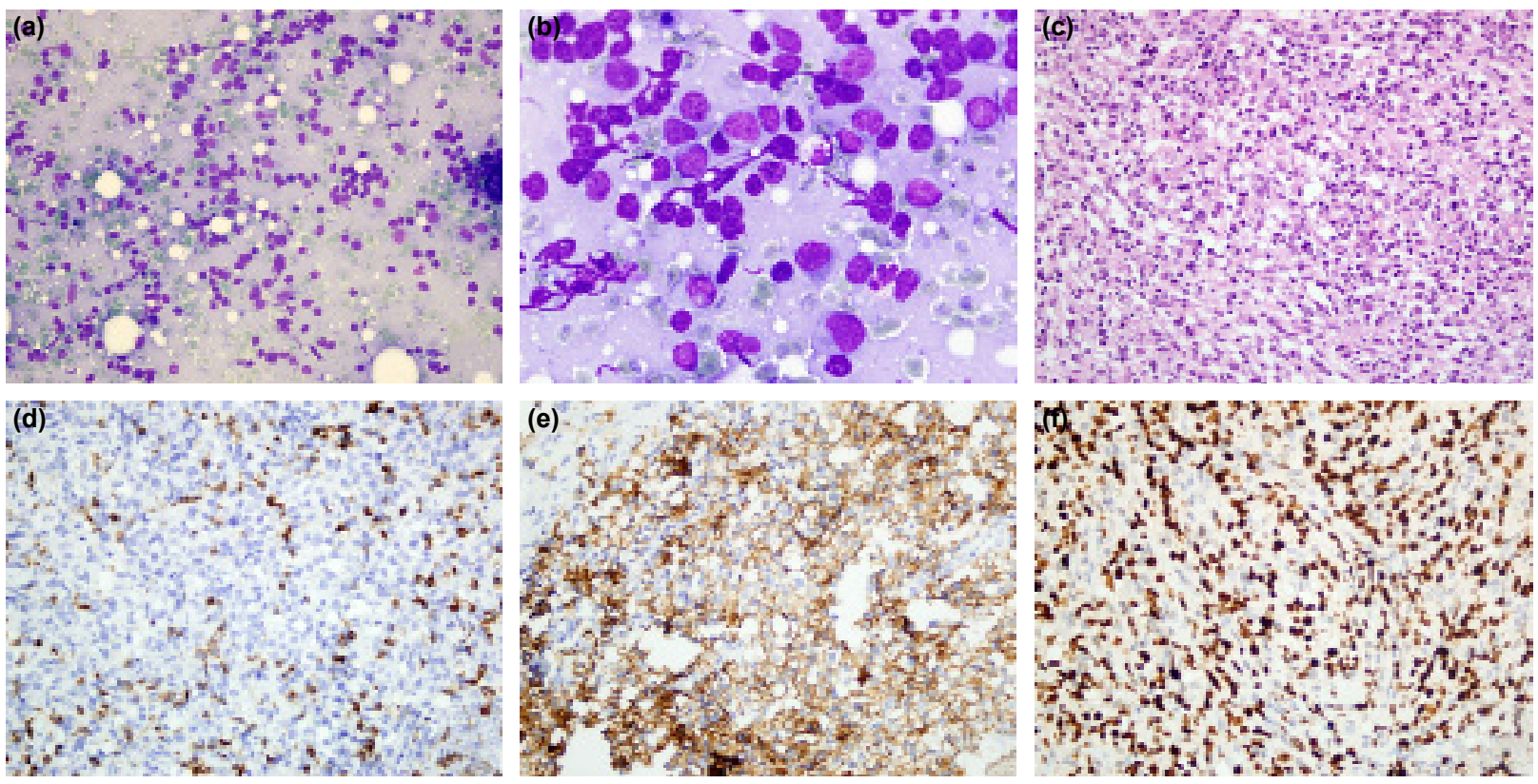

Figure 3. (a, b) Diffuse infiltration of atypical medium-to-large sized lymphoid cells with a coarse chromatin pattern and occasional nuclear contour irregularity (a: May-Grünwald-Giemsa [MGG] x200, b: MGG x1000), (c) Diffuse infiltration of atypical medium-to-large sized lymphoid cells (Hematoxylin and eosin x200), (d) Immune expression of CD3 in mature T lymphocytes, (e) Diffuse immune expression of CD20 in atypical lymphoid cells (x200), (f) Approximately $90 \%$ Ki-67 proliferation index of atypical lymphoid cells (x200). 
A histopathological correlation was determined in 22 of 32 patients with a diagnosis of suspected malignancy and malignancy in FNAC. The distribution of diagnoses of these 22 cases detected using FNAC was as follows: lymphoma $(n=9)$ (Figs. I-3), metastasis of malignant epithelial tumor (Figs. 4-6), small blue round cell tumor $(n=2)$, indifferent malignant tumor metastasis $(n=I)$, and rarely seen malignant cells $(n=l)$. The histopathological correlation of these cases is shown in Table 2.

All 4 cases with atypia of undetermined significance and a histopathological correlation raised the suspicion of atypical lymphoid cells. In 3 of these 4 cases, histopathologically reactive lymphoid hyperplasia was detected, and in the remaining patient, poorly differentiated metastatic carcinoma was identified.

The histopathology results of 9 patients with a histopathological correlation and a benign FNAC diagnosis revealed reactive lymphoid tissue $(n=7)$ and a dermatopathic lymph node $(n=2)$.
High-grade B-cell lymphoma was found in both of the 2 cases included in the nondiagnostic category due to necrosis observed with FNAC.

The results of the histopathological evaluation of 37 patients $(95 \%)$ with a histopathological correlation were found to be consistent with the FNAC examination and evaluation results (Table I).

All of the patients with benign and malignant diagnosis established based on FNAC findings were found to have a histopathological correlation (Table I). Of the 2 cases (5\%) that were found to be incompatible with the histopathological correlation was diagnosed as atypia of undetermined significance and I as suspected malignancy in the FNAC results (Table 3 ). Thirteen patients received a histopathological diagnosis of lymphoma (Hodgkin's lymphoma: $n=3$; non-Hodgkin's lymphoma: $n=10)$. Eleven (84.6\%) of these patients were diagnosed with a malignancy or suspected malignancy using FNAC. In 9 of I I patients diagnosed with a malignancy or suspected malignancy, FNAC cytologically
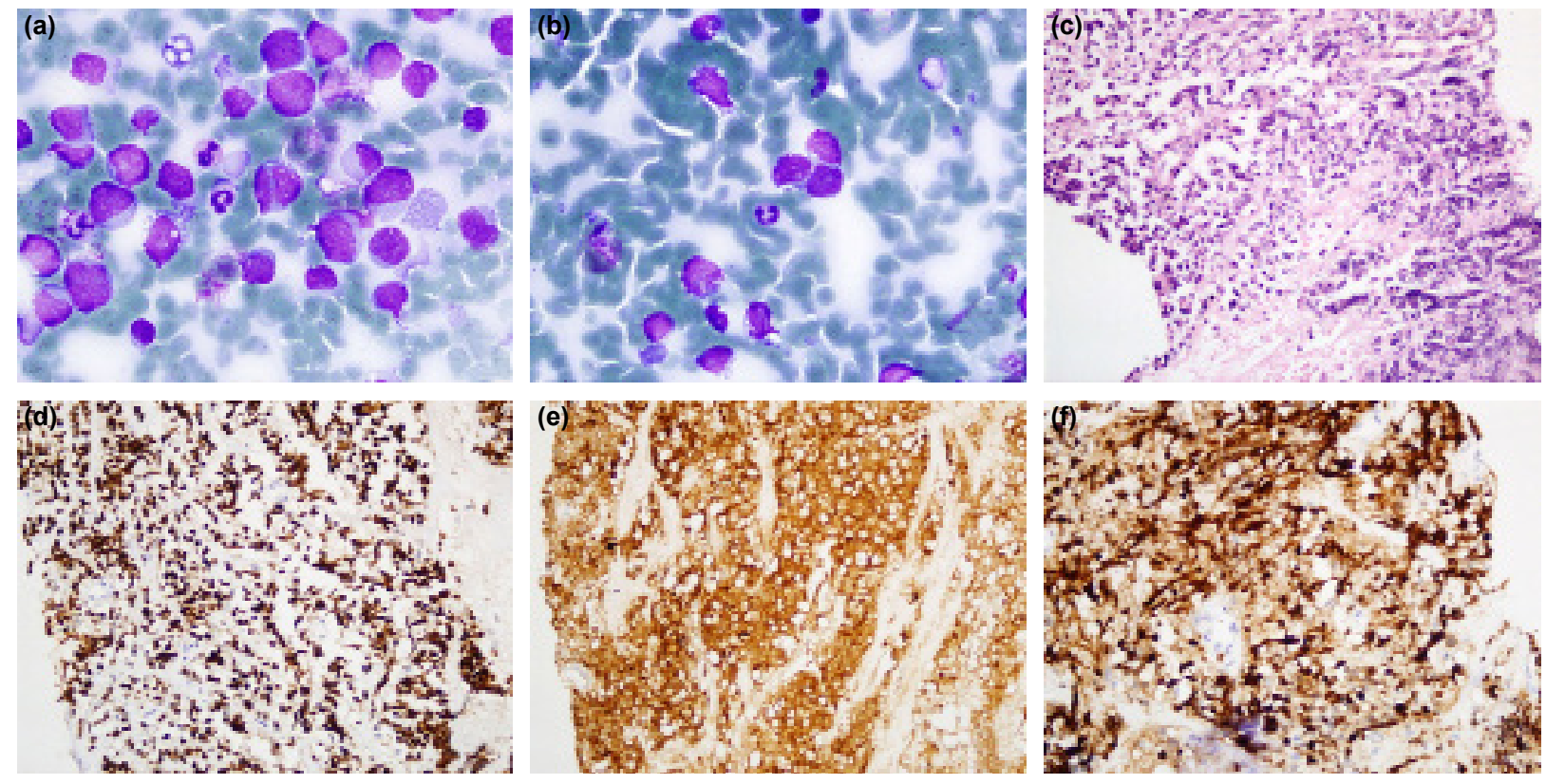

Figure 4. (a, b) Small tumor cells with a hyperchromatic nucleus and a small cytoplasm are disintegrated one-by-one or combine in interconnected groups (May-Grünwald-Giemsa x1000), (c) Tumor infiltration harboring crush artifact and necrotic foci (Hematoxylin and eosin x400), (d-f) Thyroid transcription factor 1 in tumor, (d) Positive reaction with synaptophysin, (e) Antibodies, (f) Ki-67 proliferation index of nearly $100 \%$ in the tumor.

(a)

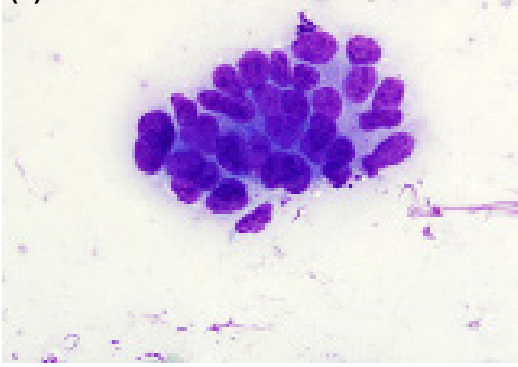

(b)

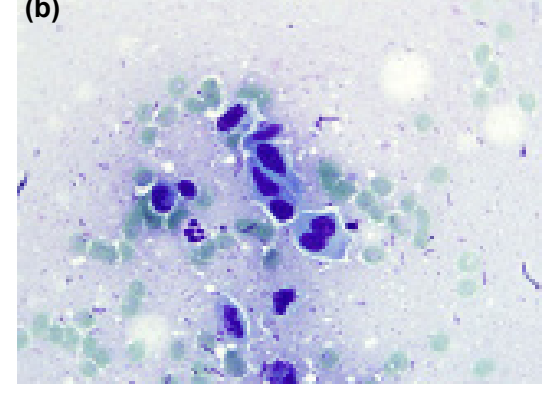

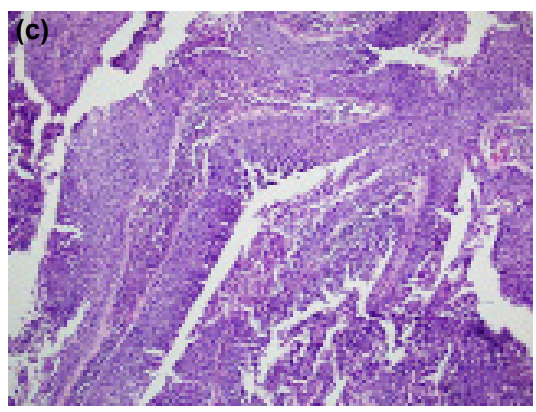

Figure 5. (a) Tumor cells with coarse hyperchromatic nucleus, coarse chromatin, and narrow pale cyanophilic cytoplasm (May-Grünwald-Giemsa [MGG] x400), (b) Tumor cells with prolonged, highly hyperchromatic nucleus and dense cyanophilic cytoplasm (MGG $\mathrm{x} 400$ ), (c) Tumor islands infiltrating lymph node parenchyma. 

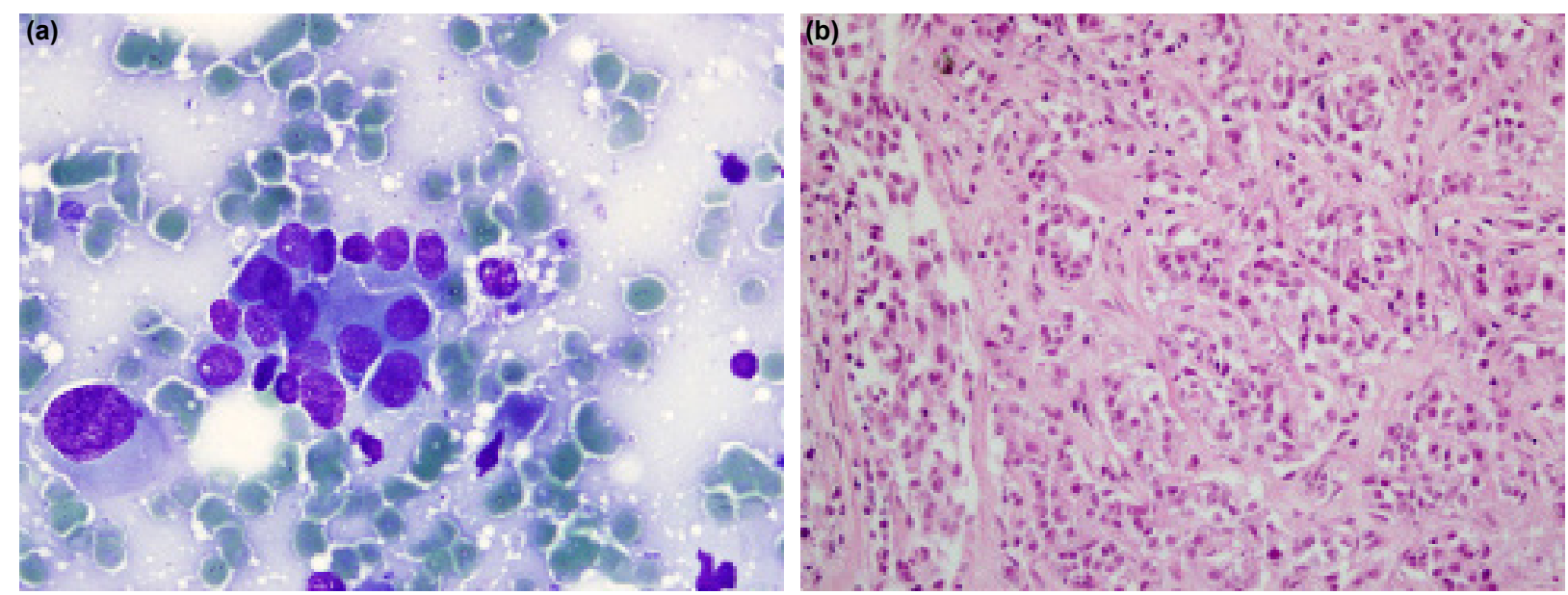

Figure 6. (a) Tumor cells with large hyperchromatic, pleomorphic nuclei and faint cyanophilic cytoplasm forming a tubular array (MayGrünwald-Giemsa x1000), (b) Tumoral infiltration forming abortive tubuli (Hematoxylin and eosin x200).

identified 2 cases with Hodgkin's lymphoma and 7 with non-Hodgkin's lymphoma.

The remaining 2 cases were diagnosed with malignancy but no specific diagnosis was made suggestive of lymphoma. One of these 2 cases was diagnosed as diffuse large B-cell lymphoma in the histopathology report and was consid-

Table 2. Cyto-histopathological diagnosis of cases with a histopathological correlation and FNAC results reported as malignant lesions

\begin{tabular}{|c|c|c|c|}
\hline Cytological diagnosis & & Histopathological diagnosis & $\begin{array}{l}\text { Number } \\
\text { of patients }\end{array}$ \\
\hline \multirow[t]{6}{*}{ Non-Hodgkin's lymphoma } & Additional comment & & 5 \\
\hline & Low-grade non-Hodgkin's & CLL, $n=2 ; F L, n=I$ & \\
\hline & lymphoma, $n=3$ & & \\
\hline & High-grade non-Hodgkin's & DLBCL, $n=I$ & \\
\hline & lymphoma, $\mathrm{n}=\mathrm{I}$ & & \\
\hline & Non-Hodgkin's lymphoma & $\mathrm{FL}, \mathrm{n}=\mathrm{I}$ & \\
\hline Hodgkin's lymphoma & & Hodgkin's lymphoma & 3 \\
\hline Lymphoma & & Suspicion of Hodgkin's lymphoma & 1 \\
\hline \multirow{4}{*}{$\begin{array}{l}\text { Malignant small blue } \\
\text { round cell tumor }\end{array}$} & & & 2 \\
\hline & & & \\
\hline & & Metastasis of small cell carcinoma, $\mathrm{n}=\mathrm{I}$ & \\
\hline & & DLBCL, $n=1$ & \\
\hline Metastasis of malignant & & & 8 \\
\hline \multirow[t]{7}{*}{ epithelial tumor } & Metastasis of squamous cell & Metastasis of squamous cell & \\
\hline & carcinoma, $n=3$ & carcinoma, $\mathrm{n}=3$ & \\
\hline & Metastasis of adenocarcinoma, $\mathrm{n}=\mathrm{I}$ & Metastasis of breast carcinoma, $\mathrm{n}=\mathrm{I}$ & \\
\hline & Metastasis of small cell carcinoma, $n=I$ & Metastasis of small cell carcinoma, $n=I$ & \\
\hline & Metastasis of papillary thyroid & Metastasis of papillary thyroid & \\
\hline & carcinoma, $\mathrm{n}=\mathrm{I}$ & carcinoma, $\mathrm{n}=\mathrm{I}$ & \\
\hline & Metastasis of breast carcinoma & Metastasis of breast carcinoma & \\
\hline Metastasis of undifferentiated & Metastasis of poorly differentiated & & \\
\hline malignant tumor & $\begin{array}{l}\text { carcinoma or metastasis of } \\
\text { malignant melanoma }\end{array}$ & Metastasis of malignant melanoma & 1 \\
\hline \multirow[t]{5}{*}{ Rarely seen malignant cell } & & & 2 \\
\hline & & High-grade non-Hodgkin's & \\
\hline & & lymphoma, $n=1$ & \\
\hline & & Metastasis of poorly differentiated & \\
\hline & & carcinoma, $n=1$ & \\
\hline
\end{tabular}


Table 3. Distrubution of cases with discordant cyto-histopathological correlation

\begin{tabular}{|c|c|c|c|}
\hline Cytological diagnosis & $\begin{array}{l}\text { Additional cytopathology } \\
\text { comments }\end{array}$ & Histopathological diagnosis & $\begin{array}{l}\text { Number } \\
\text { of patients }\end{array}$ \\
\hline $\begin{array}{l}\text { Atypia of undetermined } \\
\text { significance }\end{array}$ & Atypical lymphoid tissue & $\begin{array}{l}\text { Metastasis of poorly differentiated } \\
\text { carcinoma }\end{array}$ & 1 \\
\hline Suspected malignancy & Suspicion of non-Hodgkin's lymphoma & Reactive lymphoid tissue & I \\
\hline
\end{tabular}

ered malignant in the cytology findings and included in the malignant small blue round cell tumor group. The cytological diagnosis of suspected malignancy in the other case could not be more specific because of the rarity of the malignant cells. Two cases were placed in the nondiagnostic category because only necrosis and no viable cells were observed in the smears. The histopathological evaluation also revealed the presence of necrosis in the tissue sections of the 2 cases with high-grade B-cell non-Hodgkin's lymphoma.

The sensitivity, specificity, PPV, NPV, and accuracy of FNAC when compared with histopathological diagnosis was $95.4 \%$, 94.1\%, 95.4\%, 94.1\%, and $94.9 \%$, respectively. The FN for the FNAC results was $2.4 \%(\mathrm{I} / 4 \mathrm{I})$, and the FP rate was $2.4 \%(\mathrm{I} / 4 \mathrm{I})$.

\section{DISCUSSION}

It is well known that FNAC can provide an accurate diagnosis in FNAC-reactive lymphoid hyperplasia, infectious disease, granulomatous lymphadenitis, and metastatic tumors, as well as assisting in the initiation of rapid treatment without the need for an excisional biopsy. ${ }^{[10]}$

When supported by clinical and radiological findings, FNAC is a diagnostic method that can prevent unnecessary surgery and distinguish with high accuracy between benign and malignant lesions. ${ }^{\left[{ }^{\prime I}\right]}$ Although FNA is a simple, fast, and inexpensive method to diagnose head and neck masses and is increasingly used in routine practice, histopathological evaluation is still considered to be the gold standard for the final diagnosis. ${ }^{[3,12]}$

There are studies evaluating the efficacy of FNAC in head and neck masses in the literature. Ashraf et al. ${ }^{[13]}$ investigated the efficacy of FNAC in thyroid and non-salivary gland head and neck masses.

The sensitivity, specificity, PPV, NPV, and accuracy were found to be $92 \%, 100 \%, 100 \%, 83 \%$, and $94 \%$, respectively, based on the FNAC results of 19 lymph nodes. These findings were similar to the rates we found in the present study $(95.4 \%, 94.1 \%, 95.4 \%, 94.1 \%$, and $94.9 \%)$. However, other studies in the literature have reported lower rates of specificity for lymph node FNAC.

Hafes et al. ${ }^{[14]}$ reported that when the presence of atypical lymphoid cells was suspected, FP rates were high because they indicated the possibility of lymphoma, resulting in lower specificity (67.2\%).
In the current study, a patient with the suspicion of lowgrade non-Hodgkin's lymphoma was diagnosed as suspected malignancy and the histopathological evaluation revealed the presence of reactive lymphoid tissue. The specificity $(94.1 \%)$ of our study, in which only I FP case was detected, was significantly higher than that of the study by Hafes et al.

The sensitivity and specificity of FNAC in metastatic disease have been reported to be $83 \%$ to $97 \%{ }^{[15-19]}$ and $91 \%$ to $100 \% .{ }^{[15-19]}$ Although FNAC is an accepted technique to determine the possibility of infectious/inflammatory diseases and metastatic disease, its place in the diagnosis of lymphoproliferative disease remains controversial. ${ }^{[20-23]}$

There are also studies investigating the accuracy of FNAC in the diagnosis of lymphoma. ${ }^{[23]}$ The success rate of FNAC has been reported to vary between $38 \%$ and $88.8 \%$ in the identification of the correct subtype of lymphoma. [24] In addition to cytomorphology and modern flow cytometric techniques which analyzes surface determinants, FNAC is a very reliable method in the diagnosis of specific lymphoma, in subtyping and differentiating lymphoma subtypes from reactive lymphadenopathies when used by an experienced operator. ${ }^{[25]}$ However, some studies in the literature have reported a lower sensitivity (72\%) for FNAC in neck lymphomas, and open surgical biopsy is recommended. In the present study, II (84.6\%) of I 3 patients with a histopathological determination of lymphoma were diagnosed with malignancy or malignancy suspicion using FNAC.

In 9 of II patients, FNAC cytologically diagnosed lymphoma, and differentiated Hodgkin's lymphoma from nonHodgkin's lymphoma. In 2 cases of lymphoma, the FNAC result was reported as malignant but a specific diagnosis of lymphoma could not be made. In this study, it can be concluded that differentiation between benign lymphoid tissue and lymphoma can be performed reliably using cytology. However, due to the necessity of a specific diagnosis for the treatment of lymphomas, a histopathological and immunohistochemical examination of Tru-Cut and/or excisional biopsy specimens is necessary.

The probability of developing malignancy has been reported to be $5 \%$ in patients under 50 years of age when the FNAC result was reported as a reactive lymph node. This rate increased in patients over 50 years of age. ${ }^{[26]}$ In the present study, no malignancy was detected in any of the patients with a histopathological correlation who had received a diagnosis of a benign lesion using FNAC. How- 
ever, due to the small number of cases with a histopathological correlation in this study, this result should be further evaluated in a series with a larger number of patients.

Considering the results mentioned in the literature, patients over 50 years of age should be approached with more suspicion and should be kept under close clinical follow-up, even if the result of FNAC was reported as a benign lesion. In this study, $95.4 \%$ of the patients who received the diagnosis of a malignant lesion in the histopathological examination also received the same diagnosis with FNAC, and the sensitivity and specificity of FNAC (94.1\%) was found to be quite high. The FN rate was $2.4 \%(\mathrm{I} / 4 \mathrm{I})$ in the current study. It has been established that FNAC may be insufficient in the diagnosis of lymph node cytology due to partial involvement of lymph nodes or fibrosis developing in a pathological process. ${ }^{[8,27]}$ In the present study, aspiration of the necrotic area of lymphoid malignancy in 2 cases led to the diagnosis of a nondiagnostic lesion.

FNAC is a fast, reliable, and efficient method. In the evaluation of pathological lymph nodes, initially performing FNAC to assist with diagnosis will help the clinician in the management of the patient and may avoid unnecessary surgical intervention.

Patients whose FNAC results are reported as benign lesions may be followed up clinically and radiologically if the possibility of a pathological or malignant process is not considered likely. However, even if the cytology result is a benign lesion, further investigation should be performed with a Tru-Cut or excisional biopsy option with the possibility of sampling and/or evaluation error in the presence of clinical suspicion.

In a case suspected of lymphoma detected on FNAC, in addition to cytological evaluation, immunohistochemical identification of subtypes requires tissue samples obtained by Tru-Cut or excisional biopsy.

Ethics Committee Approval

Approved by the Ankara Atatürk Training and Research Hospital Ethics Committee (date: 09.01.2019, no: II).

Peer-review

Internally peer-reviewed.

Authorship Contributions

Concept: A.A.A., G.Y.; Design: A.A.A., G.Y.; Data collection \&/or processing: A.A.A., G.Y.; Analysis and/or interpretation: A.A.A.; Literature search: A.A.A.; Writing: A.A.A.; Critical review: A.A.A., G.Y.

Conflict of Interest

None declared.

\section{REFERENCES}

1. Choi AH, Bolaris M, Nguyen DK, Panosyan EH, Lasky JL 3rd, Duane GB. Clinococytopathologic correlation in an atypical presentation of lymphadenopathy with review of literature. Am J Clin Pathol 2015;143:749-54. [CrossRef]

2. Ahujaa At, Yingb M, Hoa SY, Antonioa G, Leea YP, Kinga AD, et al. Ultrasound of malignant cervical lymph nodes. Cancer Imaging 2008;8:48-56. [CrossRef]

3. Saatian M, Badie BM, Shahriari S, Fattahi F, Rasoolinejad M. FNA diagnostic value in patients with neck masses in two teaching hospitals in Iran. Acta Med Iran 2011;49:85-8.

4. Anne S, Teot LA, Mandell DL. Fine needle aspiration biopsy: role in diagnosis of pediatric head and neck masses. Int J Pediatr Otorhinolaryngol 2008;72:1547-53. [CrossRef]

5. Keith VE, Harsharan SK, Jerald GZ. Fine needle aspiration biopsy of lymph nodes in the modern era: reactive lymphadenopathies. Pathol Case Rev 2007;12:27-35. [CrossRef]

6. Sun HB, Zheng XF, Zahng J. Diagnostic accuracy of fine needle aspiration biopsy of cervical lymph node: a study of 580 cases. [Article in Chinese]. Zhongua Bing Li Xue Za Zhi 2008;37:693-7.

7. Narang R, Pradhan S, Singh R. Place of fine needle aspiration cytology in the diagnosis of lymphadenopathy. Ind J Tuberc 1990;37:2931 .

8. Chhieng DC, Cangiariella JF, Symmans WF, Cohen JM. Fine needle aspiration cytology of Hodgkin disease: a study of 89 cases with emphasis on false negative cases. Cancer 2001;93:52-9. [CrossRef]

9. Wakely PE Jr. Fine needle aspiration cytopathology of malignant lymphoma. Clin Lab Med 1998;18:541-59. [CrossRef]

10. Howlett DC, Harper B, Quante M, Berresford A, Morley M, Grant $\mathrm{J}$, et al. Diagnostic adequacy and accuracy of fine-needle aspiration cytology in neck lump assessment: results from a regional cancer network over a one year period. J Laryngol Otol 2007;121:571-9.

11. Paker IO, Kulaçoğlu S, Eruyar T, Ergül G. Fine needle aspiration cytology of head and neck masses: a cytohistopathological correlation study with emphasis on false possives and false negatives. Kulak Burun Bogaz Ihtis Derg. 2013;23:163-72. [CrossRef]

12. Moatamed NA, Naini BV, Fathizadeh P, Estrella J, Apple SK. A correlation study of diagnostic fine-needle aspiration with histologic diagnosis in cystic neck lesions. Diagn Cytopathol 2009;37:720-6.

13. Ashraf MJ, Raad H, Azarpira N, Khademi B, Shishegar M, Gandomi $\mathrm{B}$, et al. Fine-needle aspiration cytological diagnosis of neck masses. Acta Cytol 2015;59:68-76. [CrossRef]

14. Hafes NH, Tahoun NS. Reliability of fine needle aspiration cytology (FNAC) as a diagnostic tool in cases of cervical lymphadenopathy. J Egypt Canc Inst 2011;23:105-14. [CrossRef]

15. Frable WJ, Frable MA. Thin-needle aspiration biopsy: The diagnosis of head and neck tumors revisited. Cancer 1979;43:1541-8.

16. Frable MAS, Frable WJ. Fine-needle aspiration biopsy revisited. Laryngoscope 1982;92:1414-8. [CrossRef]

17. Lee RE, Valaitis J, Kalis O, Sophian A, Schultz E. Lymph node examination by fine needle aspiration in paitents with known or suspected malignancy. Acta Cytol 1987;31:563-72.

18. Pilotti S, Di Palma S, Alasio L, Bartoli C, Rilke F. Diagnostic assessment of enlarged superficial lymph nodes by fine needle aspiration. Acta Cytol 1993;37:853-66.

19. Wakley PE Jr. Merits of fine needle aspiration biopsy in children: Head and neck. Diagn Cytopathol 1992;8:299-301. [CrossRef]

20. Korenblit J, Anatharaman A, Loren DE, Kowalski TE, Siddiqui AA. The role of endoscopic ultrasound-guided fine needle apiration (EUS-FNA) for the diagnosis of intra-abdominal lymphadenoapthy of unknown origin. J Interv Gastroenterol 2012;2:172-6. [CrossRef]

21. Mehmood S, Loya A, Yusuf MA. Clinical utiity of endoscopic ultrasound-guided fine needle aspiration in the diagnosis of mediastinal and intra-abdominal lymhadenopathy. Acta Cytol 2015;57:436-42.

22. Nakahara O, Yamao K, Bhatia V, Sawaki A, Mizuno N, Takagi T, et al. Usefulness of endoscopic ultrasound-guided fine needle aspiration (EUS-FNA) for undiagnosed intra-abdominal lymhadenopathy. J Gastroenterol 2009;44:562-7. [CrossRef] 
23. Hehn ST, Grogan TM, Miller TP. Utility of fine needle aspiration as a diagnostic technique in lymphoma. J Clin Oncol 2004;22:3046-52.

24. Jin M, Wakley PE Jr. Endoscopic/endobronchial ultrasound-guided fine needle aspiration and ancillary techniques, particularly flow cytometry in diagnosis deep-seated lymphomas. Acta Cytol 2016;60:326-35.

25. Caraway NP. Strategies to diagnose lymhoproliferative disorders by fine-needle aspiration by using ancillary studies. Cancer
2005;105:432-42. [CrossRef]

26. Yu GH, McGarth CM. Follow-up of morphologically reactive lymphoid proliferaitons in fine-needle aspirates of elderly patients. Diagnostic Cytopathol 2000;23:249-52. [CrossRef]

27. Rapkiewicz A, Thuy Le B, Simsir A, Cangiarella J, Levine P. Spectrum of head and neck lesions diagnosed by fine-needle aspiration cytology in the pediatric population. Cancer 2007;25:242-51. [CrossRef]

\section{Lenf Nodu Patolojilerinin Tanısında İnce İğne Aspirasyon Sitolojisi: Histopatolojik Tanılar ile Korelasyon}

Amaç: Lenf nodu ince iğne aspirasyon sitolojisi (iiAS) büyümüş lenf nodlarının değerlendirilmesinde genellikle ilk basamak olarak kullanılmaktadır. Histopatolojik değerlendirmeye kıyasla, hızlı, minimal invaziv ve ucuz bir yöntemdir. Bu çalışmada lenf nodu iiAS'nin histopatolojik sonuçlara kıyasla tanısal etkinliği araştırıldı.

Gereç ve Yöntem: Bu çalışmaya 2016-2017 yıllarında lenf nodu iïAS uygulanan I7I olgu alındı. Olguların 4I'inde IiAS sonuçları trucut ve/ veya eksizyonel biyopsi ile tanı aldığı histopatolojik sonuçlar ile karşılaştıııldı.

Bulgular: Histopatolojik korelasyonu olan 13 benign (I3/I3), 3 önemi belirsiz atipi (3/4), 8 malignite şüphesi (8/9) ve I3 malign (I3/I3) olguda histopatolojik tanılar ile iïAS sonuçları arasında uyum saptandı. Tanısal duyarlılık, özgüllük, positif kestirim değeri, negatif kestirim değeri ve doğruluk sırasıyla \%95.4, \%94.I, \%95.4, \%94.I ve \%94.9 bulundu. Yalancı negatiflik ve yalancı pozitiflik sırasıyla \%2.4 ve \%2.4 saptandı.

Sonuç: Lenf nodu iiAS'i, lenf nodu patolojilerinin tanısında oldukça duyarlı ve özgül bir yöntemdir. Büyümüş lenf nodlarının değerlendirilmesinde, iliAS güvenilir bir yöntem olarak kullanılabilir.

Anahtar Sözcükler: Doğruluk; histopatoloji; ince iğne aspirasyon sitolojisi; lenf nodu. 